\title{
Strategic Partnerships and Open Innovation in the Biotechnology Industry in Belgium

\author{
Jean-Pierre Segers
}

\author{
"Successful innovation is not a single breakthrough." \\ It is not a sprint. It is not an event for the solo \\ runner. Successful innovation is a team sport, it's a \\ relay race. \\ Quyen Nguyen \\ Professor of Surgery \\ tinyurl.com/cg93kwj
}

\begin{abstract}
Strategic partnerships in the biotechnology industry allow new technology-based firms to gain a foothold in this high-cost, high-risk industry. In this article, we examine the impact of strategic partnerships and open innovation on the success of new biotechnology firms in Belgium by developing multiple case studies of firms in regional biotechnology clusters. We find that, despite their small size and relative immaturity, new biotechnology firms are able to adopt innovative business models by providing $R \& D$ and services to larger firms and openly cooperating with them through open innovation.
\end{abstract}

\section{Introduction}

The application of new discoveries and advances in science towards commercial use and for public purposes depends mainly upon actions by entrepreneurs who create new technology-based firms. However, in some industries, such as healthcare and biotechnology, the high cost of commercialization makes it unlikely that any new, small firm can succeed on its own. To overcome this challenge, many smaller firms enter into strategic partnerships with larger firms.

Although the literature on strategic partnerships is well developed, the majority of studies focus on large, established firms. There is absence of studies that look at strategic partnerships - and specifically the role of open innovation - in the development of small and innovative biotechnology firms. This article addresses this gap in the literature with a focus on new firms in the biotechnology cluster in Belgium, where there is a growing trend towards technological and market-driven relationships between large and small biotechnology firms.

For this research, a number of stock-exchange-listed biotechnology firms in Belgium are screened and monitored. Most of these new biotechnology firms are unlikely to become fully integrated pharmaceutical companies, because they are heavily dependent on their large strategic partners, especially for: marketing outlets, resource manufacturing when they reach the commercialization stage, continuing product development efforts, licensing agreements, and milestone payments.

While aiming for sustainable growth, most of the new biotechnology firms in Belgium have not yet reached this level of maturity and are acutely aware of the possibility of takeover. The objective of this article is to develop an understanding of how strategic partnerships influence the development of these new and innovative biotechnology firms and the role that open innovation might play in the success of these relationships.

This article is structured as follows. The first section provides an overview of biotechnology business models to show how strategic partnerships and open innovation are commonly leveraged in this industry. The second section describes the research methodology of this study. The third section presents the results of this study of the biotechnology sector in Belgium. In the final section, conclusions are provided. 


\section{Strategic Partnerships and Open Innovation in the Biotechnology Industry in Belgium}

Jean-Pierre Segers

\section{Biotechnology Business Models and Open Innovation}

To varying degrees, new biotechnology firms depend on strategic (technology) partnerships with other organizations or large firms. In most of the partnerships, the initial research and innovation developed by the smaller firms is transferred to their larger counterparts. According to Contracter and Lorange (2002; tinyurl.com/colwgoe), "the term "alliances" covers several governance modalities ranging from relational contracting to licensing, to logistical supply-chain relationships, to equity joint ventures or to the complete merger of two or more organizations".

According to Porter (1985; tinyurl.com/bom3jck), "the business model outlines how a company generates revenues with reference to the structure of its value chain and its interaction with the industry value system". In the biotechnology industry, the business model for a new, small company is necessarily dependent on collaboration with other organizations. As Fisken and Rutherford (2002; tinyurl.com/c2xoaxv) explain: "for a biotechnology company, the business model serves to secure value from the company's proprietary technology and know-how and is currently often heavily reliant on large (bio)pharmaceutical or established biotechnology company customers, collaborators and partners".

Biotechnology companies have traditionally used a variety of business models to enter the life sciences, pharmaceutical, or healthcare markets. Fisken and Rutherford (2002; tinyurl.com/c2xoaxv) and Pareras (2008; tinyurl.com/cch3s52) distinguish between three key business models based on the value chain structure of the biotechnology industry:

1. Product-based: this vertical business model has its origins in the "fully integrated pharmaceutical company", where medicines are developed by the company from the point of discovery up to the end of clinical trials or up to approval. According to Fisken and Rutherford (2002; tinyurl.com/c2xoaxv) this business model "aims to generate value in progressing products along the drug development process and either licensing them out to pharmaceutical and top tier biotechnology companies or taking them straight through to commercialization."

2. Platform-based: with this business model, companies develop a set of tools or integrated technologies and license them out. Revenue can be generated rel- atively quickly through contract research and services. Thus, this business model reduce risk and the need for venture capital. Parares (2008; tinyurl.com/cch3s52) calls companies following this model "royalty income pharmaceutical companies". These small companies research and develop a new drug, which they eventually license to a large pharmaceutical company in exchange for a royalty on sales.

3. Hybrid: this is the dominant business model in the biotechnology industry. It is a hybrid of the productbased and platform-based business models and focuses on generating a pipeline of products. Investors benefit from reduced risks and the possibility of nearterm revenue generation. In the hybrid business model, technology platforms are combined with services and the creation of products.

The choice of business model may depend on the type of innovation; indeed, Pisano (2006; tinyurl.com/cmx23cs) distinguishes between "types of pharmaceutical innovations which call for vertical integration and which call for alliance-building and R\&D outsourcing". However, for new, small technology companies the high risk and high cost of developing and commercializing a new product on their own make the platform-based and hybrid business models attractive.

O'Doherty (1990; tinyurl.com/cxekka3) argues that "strategic partnerships and alliances perhaps represent the greatest need but also the greatest challenge for small firms and small countries". The challenges include both determining the strategic direction of the firm but also finding "suitable and willing" partners to collaborate with. In the biotechnology industry, open innovation might have a role play in meeting these challenges and in the success of the strategic partnerships, both from the perspective of new, small companies and established, large companies. As, Nigel Sheail, Head of Global Business Development \& Licensing at Bayer HealthCare (2012; tinyurl.com/ctqbcap) says: "Partnering and even open innovation is becoming increasingly important for our industry in a world where health systems are undergoing profound transformations." According to the Holst Centre (2013; tinyurl.com/cnskktb), an independent open-innovation R\&D centre, "due to the increased complexity of physics, life-sciences, materials, electronics, software, etc., the cost of $R \& D$ is growing faster than company revenues. The goal of partnering is to share ideas and efforts, cost and risk of $\mathrm{R} \& \mathrm{D}$ and to reduce the time to market of new product generations". 


\section{Strategic Partnerships and Open Innovation in the Biotechnology Industry in Belgium}

Jean-Pierre Segers

In most traditional partnerships in the biotechnology industry, smaller firms perform research and development for the larger firms or transfer innovations to them. However, open innovation is changing the way these firms interact. In the early stages of R\&D, open innovation offers "a neutral platform for companies to jointly investigate new and emerging technologies and applications, while sharing risks and costs" (Holst Centre, 2013; tinyurl.com/cnskktb).

The open-innovation approach is providing new ways for firms of all sizes to collaborate, and it is creating opportunities for smaller companies. For example, Johnson \& Johnson's pharmaceutical division, Janssen (which was originally founded in Belgium), opened a "Concept Lab and Open Collaboration Space" in San Diego (tinyurl.com/bscccjh). This shared laboratory - and its open-plan office space - provides life-science entrepreneurs with an affordable environment for early-stage research and encourages interaction between startups. According to Weverbergh (2013; tinyurl.com/cqwgauh), "cross pollination between the corporate and the startup world - whether through corporate accelerators, venturing or open innovation like Janssen Labs - is fast becoming the trend that defines 2013".

\section{Research Methodology}

To investigate the impact of strategic partnering - and specifically the role of open innovation - on the growth and survival of new biotechnology firms, we employed a case study research design (Yin, 1984; tinyurl.com/clf7wbd). Our focus is new technology companies operating within the biotechnology clusters in Belgium. Through interviews and available secondary data, we screened a sample of stock-exchange listed biotechnology firms, which are representative of the Belgian biotechnology industry. These firms were selected based on several criteria so that the sample would include representation from each of the three business models described above (i.e., product-based, platform-based, and hybrid).

We expect to find that:

1. New biotechnology firms located in Belgium will have to work together with international (bio)pharmaceutical firms to create substantial added value.

2. The success of future new biotechnology firms in Belgium will depend on setting up strategic partnering alliances.
3. Most of the new biotechnology firms in Belgium are unlikely to become fully integrated pharmaceutical companies (i.e., they are unlikely to adopt a productbased business model).

\section{Case Study Results: Biotechnology in Belgium}

The life sciences and biotechnology have become important sources of new economic development in Belgium, and many new biotechnology firms in Belgium are university spin-offs. Due to strong collaboration between research institutes, universities, venture capitalists/high-risk finance providers, and existing large companies, strong biotechnology clusters have developed in the regions of Flanders (Ghent and Leuven) and Wallonia (Liège and Louvain-La-Neuve).

The Belgian biotechnology industry is now firmly positioned as the key player in Europe, with a market capitalization of about $30 \%$ in the eurozone. Belgium now accounts for more than 150 new biotech firms, which represent $7 \%$ of European biotechnology firms and $10 \%$ of R\&D expenditures (OECD, 2011; tinyurl.com/bqynwij).

Biotechnology clustering in Belgium is the result of a "regional innovation systems" point of view (Segers, 1996; tinyurl.com/cmt8tgr). The region-specific technology policy in Belgium (Segers, 1992; tinyurl.com/cx4uzno) has been organized around two focal points: i) the existence of state-of-the-art research potential in the country's universities and ii) emerging technology centres, charged with supporting new technology-based firms (Segers, 1993; tinyurl.com/bl58bym).

Over the years, a wide range of incentives have been created for assisting new technology-based firms. The main categories are:

- financial and fiscal incentives (e.g., the Belgian patent income deduction regime)

- employment incentives

- access to seed, venture, and growth capital

- government-supported laboratories and industryspecific collective research centres

- technology clusters and infrastructural incentives

- establishment of incubators in the proximity of universities for stimulating and assisting university spin-offs 


\section{Strategic Partnerships and Open Innovation in the Biotechnology Industry in Belgium}

\section{Jean-Pierre Segers}

The critical success factors are:

- access to key scientific personnel and mobility of researchers

- access to seed and venture capital

- the number of initial public offerings (IPOs)

- operating losses in the early stages of development

- regulatory approval from the Food and Drug Administration (FDA; fda.gov) in the United States and from the European Medicines Agency (EMA; ema.europa .eu/ema/) in the European Union

- patents and intellectual property rights

- dependence on the strategic large partner(s)

- expected revenues derived from the strategic large partner(s) (e.g., milestone payments)

- manufacturing, clinical trial and regulatory compliance capabilities

\section{Strategic partnerships}

Within Belgium's strong regional clusters, we found a large number of strategic technology partnerships between large, international, and established chemical or (bio)pharmaceutical firms and new biotechnology firms. Table 1 lists 10 biotechnology firms from this study, along with details of their strategic partnership alliances. While aiming for sustainable growth, most new biotechnology firms in Belgium have not yet reached an independent stage of maturity and are predominantly driven by the takeover alternative, as was the case in recent years for Movetis (Shire) and Devgen (Syngenta). Up to this point, only ThromboGenics, Galapagos, and UCB have succeeded in becoming mature, self-sustaining biotechnology firms. Box 1 provides further detail on the current "star" in the Belgian biotechnology industry: ThromboGenics.

We observed strong collaboration between research institutions, universities, venture capitalists, high-risk finance providers, existing large companies, and new biotechnology firms. The basic innovative activity occurs mainly in university-based new biotechnology firms (i.e., new, small firms that are spin-offs from university research centres performing state-of-the-art research).
Box 1. The case of ThromboGenics

ThromboGenics (thrombogenics.com) is a biopharmaceutical company focused on the discovery and development of innovative medicines for the treatment of eye diseases. The company was established in the 1980s as a spin-off of the University of Leuven. ThromboGenics developed over the years from a university spin-off to a fully integrated specialty pharmaceutical company. It is now the "star" amongst new biotechnology firms in Belgium.

ThromboGenics' lead product, Jetrea (ocriplasmin), has been approved by the FDA and the EMA, and the company recently signed an important strategic partnership with Alcon (Novartis) to commercialize Jetrea outside the United States (tinyurl.com/c6795v9).

On the other hand, large and international chemical or (bio)pharmaceutical firms participate in or establish joint ventures with university research centres and small, university-based new biotechnology firms. Of the new biotechnology firms in Belgium that were included in this study, most are unlikely to become fully integrated pharmaceutical companies, because they are heavily dependent on their strategic large partners, especially for marketing outlets, for manufacturing resources when they reach the commercialization stage, and for continuing product development efforts. They have to rely heavily on licensing agreements and milestone payments.

\section{Conclusions}

Our case-based analysis of the biotechnology industry in Belgium shows that strategic technology partnerships between new biotechnology firms and established, large, and international (bio)pharmaceutical companies have a significant impact on the survival and growth of these new biotechnology firms.

Our evidence supports the assertion by Fisken and Rutherford (2002; tinyurl.com/c2xoaxv): "while a small number of companies with access to a large supply of capital may be able to complete downstream integration and revert to the [fully integrated pharmaceutical company] model, the majority of biotechnology com- 


\section{Strategic Partnerships and Open Innovation in the Biotechnology Industry in Belgium}

Jean-Pierre Segers

Table 1. Sample of Belgian biotechnology firms and their strategic partnership alliances

\begin{tabular}{|c|c|c|c|c|c|}
\hline Firm & Platform & Product & Alliances/Partners & Spin-off/out & Location \\
\hline ThromboGenics & $\begin{array}{l}\text { Ophthalmic } \\
\text { medicines }\end{array}$ & Ocriplasmin (Jetrea) & $\begin{array}{l}\text { Novartis } \\
\text { Alcon (Novartis) } \\
\text { Biolnvent } \\
\text { Roche } \\
\text { Rhein Minapharm } \\
\text { Bharat Biotech }\end{array}$ & & $\begin{array}{l}\text { Flanders } \\
\text { (Leuven) }\end{array}$ \\
\hline Ablynx & Nanobodies & Alpha-pharmaceuticals & $\begin{array}{l}\text { Boehringer Ingelheim } \\
\text { Novartis } \\
\text { Merck Serono } \\
\text { Shire } \\
\text { Eli Lilly } \\
\text { Algeta }\end{array}$ & $\begin{array}{l}\text { Argen-X } \\
\text { (Nanobodies) }\end{array}$ & $\begin{array}{l}\text { Flanders } \\
\text { (Gent) }\end{array}$ \\
\hline Galàpagos & $\begin{array}{l}\text { Rheumatoid } \\
\text { arthritis }\end{array}$ & $\begin{array}{l}\text { Biofocus + Argenta: } \\
\text { drug discovery divisions }\end{array}$ & $\begin{array}{l}\text { Abbott Laboratories } \\
\text { GlaxoSmithKline } \\
\text { Eli Lilly } \\
\text { Janssen Pharmaceuticals (J\&J) } \\
\text { Servier } \\
\text { Roche } \\
\text { Ono Pharmaceuticals }\end{array}$ & $\begin{array}{l}\text { 01/2013: acquisition } \\
\text { of Cangenix (drug } \\
\text { discovery) }\end{array}$ & $\begin{array}{l}\text { Flanders } \\
\text { (Mechelen) }\end{array}$ \\
\hline Tigenix & Stem cells & ChondroCelect & Cellerix & Cellerix (acquisition) & $\begin{array}{l}\text { Flanders } \\
\text { (Leuven) }\end{array}$ \\
\hline Movetis & Gastroenterology & Resolor & Shire-Movetis & $\begin{array}{l}\text { 2010: public } \\
\text { takeover by Shire }\end{array}$ & $\begin{array}{l}\text { Flanders } \\
\text { (Turnhout) }\end{array}$ \\
\hline DevGen & RNAi-technology & Hybrid rice & $\begin{array}{l}\text { Monsanto } \\
\text { Sumitomo Chemical }\end{array}$ & $\begin{array}{l}\text { 09/2012: public } \\
\text { takeover by } \\
\text { Syngenta }\end{array}$ & $\begin{array}{l}\text { Flanders } \\
\text { (Gent) }\end{array}$ \\
\hline $\begin{array}{l}\text { Promethera } \\
\text { Biosciences }\end{array}$ & Cell therapy & & $\begin{array}{l}\text { Shire } \\
\text { Boehringer Ingelheim }\end{array}$ & & $\begin{array}{l}\text { Wallonia } \\
\text { (Louvain-la- } \\
\text { Neuve) }\end{array}$ \\
\hline Uteron Pharma & $\begin{array}{l}\text { Intrauterine } \\
\text { platform }\end{array}$ & & GlaxoSmithKline & $\begin{array}{l}\text { 01/2013: Uteron } \\
\text { sold to Watson } \\
\text { Pharmaceuticals } \\
\text { (Actavis: USA) }\end{array}$ & $\begin{array}{l}\text { Wallonia } \\
\text { (Liège) }\end{array}$ \\
\hline MDxHealth & MDxHealth & ConfirmMDx & Merck Serono & & $\begin{array}{l}\text { Wallonia } \\
\text { (Liège) }\end{array}$ \\
\hline UCB & $\begin{array}{l}\text { Neurology/ } \\
\text { immunology }\end{array}$ & $\begin{array}{l}\text { Zyrtec, Cimzia, Vimpat, } \\
\text { Neupro, Keppra }\end{array}$ & $\begin{array}{l}\text { AstraZeneca } \\
\text { Pfizer } \\
\text { Amgen } \\
\text { Bayer }\end{array}$ & & Brussels \\
\hline
\end{tabular}




\section{Strategic Partnerships and Open Innovation in the Biotechnology Industry in Belgium}

Jean-Pierre Segers

panies will instead need to further develop sophisticated relationship management skills in order to extract greater value from relationships with customers, collaborators and strategic partners". Our conclusion is that the future of new biotechnology firms in Belgium lies in the effective establishment of strategic partnering alliances. In future studies, the impacts of open innovation and novel business models warrant further attention.

\section{About the Author}

Jean-Pierre Segers is Dean of the Business School at PXL University College in Hasselt, Belgium (pxl.be), and he is the Chairman and co-founder of Creative Inc. (creativeinc.be). He holds a Master's degree in Applied Economics and Public Affairs and is a former researcher in the Small Business Research Institute at the University of Brussels. His main research interests are small businesses and entrepreneurship; innovation and technology management; national and regional systems of innovation; and publicprivate partnerships.

Citation: Segers, J-P. 2013. Strategic Partnerships and Open Innovation in the Biotechnology Industry in Belgium. Technology Innovation Management Review.

(cc) BY

Keywords: strategic partnerships, biotechnology, Belgium, open innovation, business models, R\&D 